Article

\title{
Islands of Good Government: Explaining Successful Corruption Control in Two Spanish Cities
}

\author{
Eliška Drápalová ${ }^{1, *}$ and Fabrizio Di Mascio ${ }^{2}$ \\ ${ }^{1}$ Department of Political Science, University of Gothenburg, 41123 Gothenburg, Sweden; E-Mail: eliska.drapalova@gu.se \\ 2 Interuniversity Department of Regional and Urban Studies and Planning, University of Turin, 10125 Turin, Italy; E-Mail: \\ fabrizio.dimascio@unito.it
}

* Corresponding author

Submitted: 17 December 2019 | Accepted: 4 April 2020 | Published: 28 May 2020

\begin{abstract}
Between 2012 and 2018, Spanish public opinion has been shaken by a seemingly endless series of corruption scandals, to the point that corruption has become one of the main long-term concerns of the Spanish population, according to nation-wide surveys. Despite the sharp rise in corruption scandals within local authorities, there are Spanish cities that have managed to limit corruption and build a transparent and efficient government, which stand out as islands of integrity and good governance. This article qualitatively investigates two cities in Spain-Alcobendas and Sant Cugat del Vallèswhich, despite being in a region with comparatively lower quality of government, have managed to successfully control corruption. We argue that the key to success is the administrative reorganization prompted by the appointment of city managers that institutionalized professional management. Findings also have implications for practitioners, meaning that complex anti-corruption legislative frameworks will not work within an overburdened administration unless the administrative structure is reformed.
\end{abstract}

\section{Keywords}

corruption; quality of government; integrity; political competition; Spain; transparency

\section{Issue}

This article is part of the issue "Fighting Corruption in the Developed World: Dimensions, Patterns, Remedies" edited by Fabrizio Di Mascio (University of Turin, Italy) and Simona Piattoni (University of Trento, Italy).

(C) 2020 by the authors; licensee Cogitatio (Lisbon, Portugal). This article is licensed under a Creative Commons Attribution 4.0 International License (CC BY).

\section{Introduction}

Over the last two decades, interest in anticorruption has gained a global dimension through the signing of multiple international conventions and the emergence of a series of transnational actors (UN, OECD, Council of Europe, European Commission, and Transparency International, among the others). Anticorruption has become an industry (Sampson, 2010), meaning that there is a marketplace of initiatives, organized and prioritized by international organizations acting like 'integrity warriors' with considerable resources and policy reach (de Sousa, Hindess, \& Larmour, 2009). The recommendations issued by these actors and their monitoring of national anti-corruption measures have been focused on a 'le- gal toolbox,' which primes certain tools such as whistleblower protection, conflict of interest regulation, staff rotation, lobbying for transparency, and so forth. Yet, the most common measures recommended in the current international anti-corruption toolkit have not proved to be effective in reducing corruption (Mungiu-Pippidi \& Dadašov, 2017).

This finding suggests looking at anti-corruption tools in a broader context by taking specific institutional dimensions into account. In the absence of a number of empowering institutional factors, the set of specific legal instruments promoted by the international integrity warriors is not likely to work (Mungiu-Pippidi \& Dadašov, 2016). Our research focuses on professional bureaucracies, which have long been recognized as an important 
institutional factor in curbing corruption (Rauch \& Evans, 2000). Yet, we lack empirical studies that explore the ways through which administrative reforms can enhance the professionalism of bureaucracy. In particular, research on institutional factors that support control of corruption at the local level of government remains sparse (Beeri \& Navot, 2013).

We address this gap in the literature by analysing the administrative reforms in two Spanish municipalities. The implementation of these reforms represents two 'islands of good government' in a country that is marked by widespread corruption at the local level (Jiménez, Villoria, \& Quesada-Garcia, 2012). Previous research on corruption in Spanish municipalities highlighted the role of political stability as a factor that may explain variation in corruption practices (Jiménez, Quesada-Garcia, \& Villoria, 2014). This finding is not consistent with most of the comparative literature on anticorruption reform, which argued that incentives for the implementation of anti-corruption reforms are generated by sustained political competition (Schnell, 2018). To address this inconsistency, we identify under what conditions a low level of political competition may support the launch and implementation of reform initiatives to raise the level of professionalism in local bureaucracies.

In doing so, we draw on two strands of literature. First, we build on those few studies in the field of political science, which highlight the virtuous circles activated by the duration of political leadership; second, we build on those accounts of public management reform that consider micro-level factors, that is changes at the level of individual organizations (Ongaro \& Valotti, 2008). The focus on micro-level factors allows for variation across individual organizations at the subnational level in countries that are marked by the existence of a larger, macro institutional framework which acts as a barrier to the implementation of reform. More specifically, our findings very much support previous research suggesting the importance of leadership by city managers for the successful implementation of reform in local government (Nalbandian, 2006; Nelson \& Svara, 2015).

The remainder of the article unfolds as follows. In the next section, we provide more detail on our theoretical framework. Then, we present the background of this study, namely the institutional patterns of Spanish local government. We outline the case selection strategy and methodology before tracking the progress of public management reform in two municipalities, Alcobendas and Sant Cugat del Vallès, which stand out for their success in administrative modernization. Finally, we discuss our findings and consider their implications for both researchers and practitioners.

\section{Theoretical Argument}

Our research focuses on the control of corruption, understood as the equilibrium between the opportunities for corruption (power discretion and resources) and the deterrents imposed by the state and society (Mungiu-Pippidi, 2015). In past decades, the effort to control corruption by curbing opportunities and strengthening legal and normative constraints has grown exponentially worldwide. Still, there seem to be few successful cases where anti-corruption programmes have been effectively implemented. For a growing number of scholars, the failure of anti-corruption initiatives lies in the inappropriate theoretical foundations that inform their design. Anticorruption efforts are influenced mainly by principal-agent approaches which assume that corruption is solvable with policies to reinforce transparency, monitoring, and sanctioning of public officials who manage public resources. Critics have argued that this assumption is flawed, especially in contexts ridden with systemic corruption where collective action problems hinder the implementation of anti-corruption interventions (Persson, Rothstein, \& Teorell, 2013, 2019). However, Marquette and Peiffer (2019) and others highlighted that collective action approach does not help anticorruption practitioners decide what to do differently, or how. The anti-corruption field has suffered from the quest for one overarching theory whereas researchers and practitioners should pay more attention to the focus and locus of corruption, that is the different types and contexts in which corruption occurs (Heywood, 2017).

The article joins the call for research underscoring targeted interventions as it focuses on appropriate contexts, where political will is available to implement the institutional fixes needed to curb corruption (Marquette \& Peiffer, 2018). The starting point of our research is the established institutionalist approach to good governance, which emphasises the role of professional bureaucracies in reducing the risks of corruption (Dahlström, Lapuente, \& Teorell, 2012). The expectation from this approach is that in cases where bureaucrats are agents of their political principals, they do not inhibit politicians' opportunistic actions. Conversely, in cases where bureaucrats act as 'trustees,' they keep politicians' abuse and misbehaviour in check. This approach draws on the agent-fiduciary dichotomy developed by Majone (2001) who identified two different logics of delegation: One logic is informed by the demand for policy-relevant expertise, in which political leaders delegate executive functions to agents within relatively constraining control mechanisms; the second logic is guided by the demand for credible commitments, meaning that leaders deliberately insulate their 'trustees' so that they may implement policies to which their leaders could not credibly commit.

We focus on the fiduciary relationship between mayors and city managers in local government. In past decades, the post of city manager has been introduced in the organizational charts of municipalities acting as a crucial link between elected officials and city departments (Klausen \& Magnier, 1998; Sancino \& Turrini, 2009). City managers are focused on the organization they lead and they consistently allocate most of their time and energy to building organizational capacity (van Dorp, 
2018). They are receptive to administrative reform since it has a positive impact on their ability to manage effectively. Thus, they are a vital cog in their organizations for launching and enacting administrative reform, increasingly through strategic management (Mitchell, 2018). This strand of literature on city managers as policy change agents leads us to expect that local governments led by them should display a greater propensity towards the implementation of those institutions (meritbased human resource policy, rules and standard operating procedures, transparency and independent watchdogs) that increase the accountability of political actors and limit their discretion over state resources (Knott \& Miller, 2008; Miller \& Whitford, 2016). Drawing on these expectations, previous studies have found a positive effect of city managers on the local government transparency and performance (Drapalova \& Lapuente, 2017; Fay \& Zavattaro, 2019).

The establishment of a fiduciary relationship between mayors and city managers makes it more difficult for political leaders to benefit from the control of resources and any lack of accountability. A fiduciary relationship may lead leaders to a complete and, in some cases, an irrevocable transfer of their political property rights in a given area in favour of their trustee. These features make political leaders reluctant to establish a fiduciary relationship with the city managers. However, a recent strand of literature has underlined that political competition can create conditions in which political leaders see, not only the potential costs of but also benefits from the launch of reforms (Berliner, 2014).

Political competition has long been recognized by research on patronage and corruption as a key factor influencing political incentives for opportunistic behaviour. According to this strand of research, political leaders who are electorally secure and who face weak opposition will have no incentive to curb corruption (Grzymała-Busse, 2007). Hence, political competition moderates the behaviour of leaders who fear punishment from voters in upcoming elections. Anticipating this effect, incumbents will abstain from corruption and put reforms into operation to 'signal' their competence and integrity (Bågenholm \& Charron, 2014). Furthermore, political competition induces political leaders to launch reforms when faced with electoral uncertainty (Berliner \& Erlich, 2015). If incumbents suspect that they are likely to lose power, they have a strong incentive to place the burden resulting from the implementation of reforms onto the shoulders of their political opponents.

Research has also argued that low political competition at the municipal level creates 'entrenched parties' able to restrict public procurement processes (Broms, Dahlström, \& Fazekas, 2019; Coviello \& Gagliarducci, 2017). The same argument has been applied to the study of transparency at the municipal level (Bearfield \& Bowman, 2017). Transparency is expected to increase when electoral competition becomes 'fiercer' (Esteller-Moré \& Polo Otero, 2012), though recent re- search failed to support the hypothesis that increased electoral pressure over the local executive enhances information disclosure (Tejedo-Romero \& Araujo, 2020). In particular, Tavares and da Cruz (2017) found the exact opposite, meaning that low political competition may determine higher levels of transparency, pointing to the idea that political stability may well be a precondition for adequate governance.

For the purposes of this article, we narrow down the scope of political stability to government longevity, that is the number of consecutive terms served by incumbents (Dowding \& Kimber, 1983). In the field of public administration, the study of the effects of political stability is an emerging field of inquiry (Mele \& Ongaro, 2014). Research on the management of EU cohesion funds has highlighted that those parties which alternate in control of government change implementation priorities according to their preferences. These changes interrupt implementation and weaken capacities (Hagemann, 2019; Milio, 2008; Piattoni \& Smyrl, 2002). Nationwide examination of public management reform has also highlighted that the continuity of incumbents favours the coherence and regularity of management over the medium to long-term, as is needed, to be able to put in place fundamental, wide-ranging reforms (Pollitt \& Bouckaert, 2014). By explicitly considering the effects of rapid and short political punctuation on public management reform (Pollitt, 2008), this research has highlighted that discontinuity of incumbents exacerbates policy-makers' natural disregard for the operational aspects of implementation. Conversely, durability supports the expectation that reforms will be maintained, thus sustaining the prolonged investment of resources in reform implementation at the operational level. This leads policy entrepreneurs such as city managers to engage in a pattern of implementation effort consistent with their professional aspirations and responsibilities (Di Mascio \& Natalini, 2013; Ramió \& Salvador, 2012).

To recap, different strands of literature highlight different effects of political competition on reforms. On the one hand, political competition provides incentives to signal a credible commitment to bring about change. On the other hand, the longevity of incumbents provides the luxury of long-term horizons that sustain the implementation of wide-ranging reforms. All this suggests that government longevity does not necessarily hinder effective anticorruption reform efforts but in fact, might sustain it under certain circumstances. The following empirical analysis is devoted to the identification of such circumstances in the Spanish context in which the fiduciary relationship between mayors and city managers has not been part of the administrative tradition (Mouritzen \& Svara, 2012). This feature of the Spanish administrative tradition makes the analysis of cases in which delegation of powers to city managers has led to broad scope reform particularly interesting. 


\section{Spanish Context}

Between 2012 and 2018, Spanish public opinion was shaken by a seemingly endless series of corruption scandals, to the point that corruption has now become one of the main long-term concerns of the Spanish population (European Commission, 2014). Hundreds of corruption charges were filed across the country. A large proportion of those charges involved numerous mayors, local politicians, and civil servants (Jiménez et al., 2012). The literature generally highlights urban planning and public procurement as the policy areas most vulnerable to corruption (Jiménez, 2009; Jiménez, Villoria, \& Romero, 2012).

The existing accounts of corruption in Spain underline a combination of factors that drive the higher occurrence of corrupt practices at the local level. These include the structural problem of capacity gaps resulting from the small size of Spanish municipalities, the lack of structures for effectively enforcing the high number of regulations, the low effectiveness of checks and balances in relation to public spending, and the strongmayor form of local government and discretionary powers associated with it (Martín \& Darias, 2011). The strongmayor type is based on the principle of individualized political leadership by Spanish mayors. The latter are not directly elected, but they must be the head of a party list. The extent of scrutiny of the performance of local government by the council tends to be limited and elections are widely regarded as contests between competing candidates for the position of mayor (Sweeting, 2012). As head of staff, the typical Spanish mayor is closely involved in running and managing the local government. The mayoral powers of appointment are considerable and they are often used to intervene and act in the organization and operation of municipal organizations (Salvador \& Pano, 2018).

The organizational development of municipalities has been shaped by national legislation that stipulates a set of positions such as the Chief Administrative Officers, who are civil servants with a professional national qualification, and who tend to conform to the role of a classical bureaucrat with a low political profile. They still have a legalist background and they can be seen to represent the Napoleonic administrative tradition. In Spain, the administrative system does not foresee a separation of management and politics such as in the UK, Sweden, or the US (Mouritzen \& Svara, 2012). However, in some larger local authorities, city managers have been appointed as officials versed with and committed to modern New Public Management techniques and skills (Wollmann, 2012). To be considered a city manager, two conditions have to be fulfilled. Firstly, the city manager should occupy a position of hierarchical superiority to the other civil servants who should report to them. Secondly, municipal finances and budget, general services, personnel hiring, and information systems should be under their direct control and supervision (Fernandez, 2013). City managers' primary responsibilities are to introduce efficiency in the local management and make sure that the strategies devised by politicians are executed and evaluated.

\section{Case Selection Strategy and Methodology}

Our analysis is based on a qualitative comparative case study of two Spanish cities that present above-average levels of transparency and administrative capacity despite being located in regions with numerous corruption scandals and low-quality regional government as indicated by the European Quality of Government Index (Charron, Lapuente, \& Annoni, 2019). These pockets of good government are Alcobendas in Madrid and Sant Cugat del Vallès in Catalonia. Spain provides an ideal setting to examine the factors that affect control of local corruption because of the tremendous subnational variation and the presence of cities with remarkably different levels of performance (Parrado, Dahlström, \& Lapuente, 2018).

Alcobendas and Sant Cugat del Vallès share many similarities in the setup of their organisation, political competition, and socioeconomic composition. Both are medium-sized cities, resourceful but with a high level of inequality, with a similar economic model, and a strong business sector. They stand in stark contrast to their medium-sized neighbouring cities as they were not targeted by corruption investigations. In 2009 the Pretoria scandal uncovered corruption related to planning issues linked to politicians of the Catalan Socialist Party (Partit Socialista de Catalunya) in medium-sized cities such as Santa Coloma de Gramenet and Badalona. In 2014, the mayors of two medium-sized municipalities in the Madrid region, Parla and Valdemoro, were hit by the Púnica scandal as a part of graft investigation involving local government construction contracts.

The four cities hit by corruption scandals shared two features. First, a stable area of professional management had not become institutionalized in these municipalities through the introduction of a city manager before the eruption of corruption scandals. Second, the political environment was marked by a low level of competitiveness. In both Badalona and Santa Coloma de Gramenet, the Catalan Socialist Party had been in power since 1979 until the eruption of the Pretoria scandal; in Parla, the Spanish Socialist Party (Partido Socialista Obrero Español) had been in power since 1979 until the eruption of the Púnica scandal; the latter hit Valdemoro which had been managed by the Popular Party (Partido Popular) since 1999. These four cases, therefore, provide support for the argument that low political competition is detrimental to corruption control. Yet, this argument does not hold for Alcobendas and Sant Cugat del Vallès which were not hit by corruption scandals despite the low level of competitiveness of their political environment. In Alcobendas, the Popular Party had been in power from 2007 to 2019 after 24 years of Socialist government whereas in Sant Cugat del Vallès the Catalan nationalist party Convergence and Union (Convergència $i$ Unió) had been in power from 1987 to 2019. 
The lack of sustained political competition in Alcobendas and Sant Cugat del Vallès has also been associated with a high level of transparency, an indicator that signals the control of corruption (Benito, Guillamón, \& Bastida, 2015). Transparency has also been put at the centre of the anticorruption packages adopted by Spanish governments as a reaction to widespread judicial investigations into local corruption (Villoria, 2020). If we take data on the quality of information available on the municipal websites, Alcobendas and Sant Cugat del Vallès, in 2014, scored 88 and 98 respectively out of 100, outclassing Badalona, Valdemoro, and Parla, which ranged from 48 to 56 . Data were collected by the University of Barcelona and contain an index made up of 52 different components adapted from the national transparency law in 2013 (InfoParticipa, 2017). We have selected this indicator because it covers a large number of Spanish municipalities. Alcobendas and Sant Cugat del Vallès also exhibited a good level of administrative capacity as revealed by indicators that measure the ability of Spanish municipalities to speed up tax collection and payments to providers in 2014 . As shown by Table 1 , the transparency and administrative capacity gap between 'good' (Alcobendas and Sant Cugat del Vallès) and 'rotten' apples (Parla, Valdemoro, Santa Coloma de Gramenet, Badalona) has further increased in the period from 2014 to 2017.

The next empirical section unveils how the appointment of city managers-a key institutional feature that distinguished the 'good' from the 'rotten' apples-set in motion a sequence of administrative reforms that shielded the well-performing cities from corruption investigations as well as improving levels of transparency and administrative capacity. The framing of our qualitative study connects the research question to broader theoretical conversations in the field (Ospina, Esteve, \& Lee, 2017). More specifically, we apply what Ashworth, McDermott, and Currie (2019) call 'abductive method' that starts with formulating an empirical puzzle and combines inductive and deductive approaches to solve it. We rely on case study research that allows us to explain why we observe particular relationships and which can help us to clarify gaps and inconsistencies in theory (Rubin \& Baker, 2019; Yin, 2014). We employ process tracing that involves the careful use of evidence for the identification of sequences linking contexts and outcomes (Bennett \& Checkel, 2014; George \& Bennett, 2005). The subna- tional approach allows us to hold macro-conditionssuch as national regime type and institutional settingconstant. In contrast, the specific factors that this theory considers relevant to the level of corruption are allowed to vary (Snyder, 2001).

The empirical analysis is based on press reports, documents provided by both city halls and administrations, archival research, secondary literature, public declarations, as well as 25 interviews with local experts, politicians, civil servants, activists, and business association representatives, conducted between 2013 and 2015. Interviews were based on a semi-structured questionnaire and partially transcribed and translated by one of the authors. The questionnaires and the list of interviews are available upon request. For each case, we outline the main characteristic of local government and trace the changes carried out on over the last two decades.

\section{Empirical Analysis}

\subsection{Alcobendas}

Alcobendas is located in the Madrid Region which has been deeply affected by corruption scandals. The best known are the Gürtel investigation, which engulfed three mayors (Majadahonda, Boadilla del Monte, and Pozuelo de Alarcón) and three former MPs of the regional parliament (Dahlström \& Lapuente, 2017), and the Púnica scandal that embroiled six mayors (among others Parla, Valdemoro, and Torrejón de Velasco) just within the Madrid region. Over the last 50 years, Alcobendas has grown from a small agrarian village to a thriving midsized city with over 110,000 inhabitants. Once a dormitory town, it has now developed into a business, industrial, and service centre with low unemployment, high levels of entrepreneurship, and a sizeable middle class. Within the Madrid context, the trajectory of Alcobendas is unique as city manager roles outside Catalonia are still exceptional. Surrounding municipalities with similar political and economic characteristics that were involved in the wave of corruption scandals during the Púnica and Gürtel investigations have not adopted a city manager structure.

While corruption scandals shook the surrounding cities, Alcobendas collected international awards for administrative innovation and good management. In 2016, it was the first local government in Europe to be handed

Table 1. Transparency and administrative capacity in Spanish municipalities.

\begin{tabular}{lcccccc}
\hline Indicators & Alcobendas & Parla & Valdemoro & Sant Cugat & Santa Coloma & Badalona \\
\hline Transparency (2014) & 87.8 & 56.1 & 53.66 & 97.56 & 95.12 & 47.9 \\
Transparency (2017) & 84.62 & 50 & 53.85 & 96.15 & 100 & 55.77 \\
Tax collection (days, 2014) & 51.55 & 73.88 & 59.98 & 40.33 & 66.81 & 48.07 \\
Tax collection (days, 2017) & 29.84 & 91.58 & 36.26 & 30.86 & 80.36 & 37.68 \\
Payment to suppliers (days, 2017) & 17 & 346 & 321 & 22 & 8 & 43 \\
\hline
\end{tabular}

Source: Authors' own elaboration with data from the Ministry of Finance of Spain (2017) and InfoParticipa (2017). 
the European Foundation for Quality Management excellence award that recognized the commitment to quality and continual improvement of public services. It was also one of the Spanish cities that made information available on their website before the adoption of the national transparency law in 2013. It ranked as one of the most transparent cities in Spain according to the City Hall Transparency Index as it scored 99 out of 100 against a national average of 70 in 2010. The City Hall Transparency Index, developed by the Spanish chapter of Transparency International, measures the level of transparency of the 110 largest Spanish City councils through an integrated set of 80 indicators.

How did this ordinary city manage to maintain its clean reputation and control opportunities for corruption effectively while other similar cities failed? The success builds on a sequence of administrative reforms set in motion during the last two mandates of the Socialist politician José Caballero who had been mayor of Alcobendas in the period 1983-2007. The first substantial organisational change occurred between 1991-1995 when the executive created a Central Organisation and Coordination Unit that implemented management by objectives and adopted the first strategic plan (Iglesias Alonso, 2006). This new unit was guaranteed the necessary resources and it was put under the political leadership of the deputy mayor. Subsequently, Alcobendas had a consulting company evaluate and design a potential new organizational model. According to the former mayor, the municipality was inspired by the spread of the city manager structure in Catalonia. The new model was based on the introduction of a dual organizational structure with the appointment of a city manager as 'general coordinator' in 1999 (Iglesias Alonso, 2006; Palacios, Fulgueiras, \& Catalina, 2002). As the former mayor of Alcobendas declared:

Besides introducing new policies, we needed a shift in the organization. The organization had remained largely obsolete and we faced serious difficulties formulating complex policies and long-term planning. We needed a manager who would centralize and coordinate projects. So, we tended towards a new organizational model that delegated decision making powers from the political to the managerial level, ensuring the coordination between the public and private sector in the management of development projects. (Former mayor of Alcobendas, personal communication)

Thus, the organisational reform aimed to deliver public services more effectively and improve internal control and coordination within the administration. It has separated the political mandate and strategy from administrative direction and reinforced internal oversight and external accountability. A critical component of the reform was the adoption of so-called Municipal Action Plans that established the main guidelines and priorities of the legis- lature that determine the political communication strategy, the budget, and the implementation (Iglesias Alonso \& Villoria, 2010). These Municipal Action Plans offered a broad citywide accountability mechanism and they were supported by the city manager because they limited the discretion of both elected officials and public employees. They also motivated the city manager to accomplish the city's priorities and demonstrate his own effectiveness as leader of the managerial sphere.

The city manager had ties with the deputy mayor and this reassured the mayor that the new administrator was committed to accountability and political responsiveness. His previous experience in public management made him knowledgeable about administrative reform processes and this instilled respect for his administrative competence in the eyes of the mayor. The city manager engaged in a pattern of sustained effort consistent with his responsibilities and previous experience and he was also able to cultivate a relationship with the mayor based on mutual respect. The effect of the constructive relationship between political and managerial leadership was strengthened by a number of new governance arrangements. First, the city manager's office was incorporated into the department of economy. With this move, resources were expanded while enhancing coordination capacity. Second, the oversight of hiring procedures was entrusted to the city manager to ensure the coherence of personnel recruitment with the Municipal Action Plans. Third, the city manager created a planning and evaluation unit within his personal staff with the task of centralizing and coordinating data collection and analysis.

The development of governance arrangements benefited from the strong support of the Socialist leadership from 1995 to 2007, a period in which pursuit of comprehensive administrative modernization was a clear objective of the mayor. The interviews suggest that the longevity of the Socialist leadership was an important context factor for administrative reforms that needed a prolonged period to be implemented effectively:

The critical element of the transformation was, in my opinion, the political stability of the municipal government. We have had a strongly united group, without internal divisions, a coherent team, that avoids wasting time in internal wars and that facilitates the work and increases our credibility....We had to show the citizens that we do things, but not just by responding [to their requests], we had to be able to foresee [their requests] in advance. We had to be one step ahead of them. (Former mayor of Alcobendas, personal communication)

Nevertheless, government longevity did not mean that the incumbents did not face any electoral pressure. In 1995, the Popular Party won in Madrid's regional election as well as in many surrounding cities previously held by the Spanish Socialist Party. The decreasing electoral support for the Spanish Socialist Party in the region pushed 
the incumbent mayor to showcase himself as a good administrator in a context where the regional government and the large majority of surrounding cities were under the control of the Popular Party. This set in motion the transformation of the governance structure. The implementation process was effective enough to protect the city manager structure from the potential effects of government alternation that occurred in 2007 when the Popular Party won the majority in the local elections.

Positive perceptions about the tangible results of the organizational model implemented under the Socialist leadership provided further impetus for the refinement of the administrative reform policy under the leadership of the new mayor, Ignacio Garcia Vinuesa, who did not remove the city manager he inherited from the outgoing government. The new political leadership, thus, took advantage of the city manager's competence, ensuring that the shift in political control did not mean an interruption of the administrative reform, which continued under the leadership of the city manager who ran the municipality from 1999 until 2015.

\subsection{Sant Cugat del Vallès}

With a population of roughly 100,000 inhabitants, this bedroom community was once a small agrarian village that has undergone vertiginous growth since 1980 due to suburbanization from Barcelona and immigration. After rapid modernization, the main economic activity is now in the service sector, telecommunications, and construction. Within the Catalan context, Sant Cugat del Vallès is a city with above-average performance in terms of administrative performance. Like in the case of Alcobendas, several national and international awards attest the quality of public services. In 2009, Sant Cugat del Vallès was the final winner in the European Public Sector Award theme 'Leadership and Management for Change.' In 2010, the Agency for Evaluation and Quality of the Spanish Ministry of Finance recognized the city reform program with the seal of good practices in internal management. In 2010, the municipality also achieved the highest score of 100 in the City Hall Transparency Index.

Sant Cugat del Vallès has been governed for almost two decades by the conservative nationalist party Convergence and Union. It was a federation of two constituent parties, the larger Democratic Convergence of Catalonia (Convergència Democràtica de Catalunya) and the smaller Democratic Union of Catalonia (Unió Democràtica de Catalunya). It dissolved in 2015 and this enabled the left-wing independentist Republican Left of Catalonia (Esquerra Republicana de Catalunya) party to take over in Sant Cugat in 2019. In 1987, for the first time, Convergence and Union won the local election in Sant Cugat with an ample majority, and Joan Aymerich Aroca became mayor of the largest city governed solely by Convergence and Union. During the following years, the city continued to grow considerably, putting existing public services under pressure. Although plans al- ready existed, it was only the new mayor, Luis Recoder (Convergence and Union), who initiated the reorganisation of the local public administration after a narrow local election win in 1999 in a context where the Catalan Socialist Party increased its share of votes in the regional elections while reinforcing its control over surrounding cities. Despite the continuous electoral support giving Luis Recoder strong mandate, the local executive was not free from pressure. As the largest city governed by Convergence and Union, the executive team felt pressure to showcase Convergence and Union policies and management (former mayor of Sant Cugat, personal communication).

As a response to Catalan Socialist Party's growth in the 1999 elections, the new mayor opted for the introduction of a new organizational model that distinguished the political from the managerial sphere. The new model hinged upon the introduction of a city manager, a position that had already been appointed by early adopters pioneering the diffusion of a variation of the US city manager system in the Catalan region. The new system was deemed more modern and effective and it was introduced because the new mayor wanted to signal his commitment to high-quality governance. The first city manager, Jordi Turull i Negre, was selected from the ranks of senior civil servants who had been loyal to Convergence and Union. He had served in top positions under the mayors of Curb, Sant Vicenc de Castellet, and Sant Adrià de Besòs. In 2004, he left the position of city manager in Sant Cugat del Vallès when he became an elected member of the Catalan Parliament.

The introduction of the city manager triggered a conflict with civil servants who regarded the new figure as an additional layer of control and not as the coordinator between the political and managerial spheres. However, the relationship of mutual trust and collaboration between the mayor and the city manager gradually overcame the civil servants' opposition to the new organizational model. By focusing on data collection and evaluation of institutional performance for decisionmaking purposes, the city manager actively signalled that he wanted to minimize any intrusion into civil servants' affairs (economic deputy of Sant Cugat, personal communication).

The resignation of Jordi Turull i Negre did not imply an interruption in the implementation process of the new organizational model. Local elections in 2003 confirmed support for the incumbent mayor, Luis Recoder, who appreciably increased his share of the votes. Electoral results provided a further impetus for the refinement of the organizational model under the leadership of a new city manager. In 2004, the City council set out to develop a Balanced Scorecard and strategic planning (Plan Ciudad) as tools for improving the communication between political executives and the administrative structure. These tools were also used by the city manager for allocating resources and managing programs. In 2005, Luis Recoder, together with the 
deputy for the economy Jordi Joly, decided to transform the Municipal Autonomous Agency for Tax Management into the Institute of Strategic Management, Economic Promotion and Information Society (IGEPESI). This new institution would pilot innovation and reform of the whole structure of the municipality (economic deputy of Sant Cugat, personal communication; Turull i Negre \& Vivas Urieta, 2003). Since 2007 the Office of Strategic Management of IGEPESI had worked on the definition and development of a new system named Strategic Alignment and Competitiveness Plan (PACTE). This plan was based on the academic work being undertaken at ESADE Business School, located nearby and renowned for advanced studies in performance management:

Major changes were implemented during the administration of former Mayor Recoder. Luckily, we hired very competent people from ESADE, who designed the PACTE [Strategic Alignment and Competitiveness Plan] consisting of a council to plan policies with a clear relationship between objectives and costs but also a clear division between political leadership and the expert knowledge of municipal technicians. (Former mayor of Sant Cugat, personal communication)

The Strategic Alignment and Competitiveness Plan was implemented fully in 2008 and complemented the dual organizational structure (Recoder \& Joly, 2010). The government also implemented an e-purchasing system which streamlined the entire circuit of purchase, limited the number of procedures, and increased control and transparency in public procurement, a traditional risk zone for corruption. The transparency of public procurement was further strengthened under the leadership of the new mayor Merce Conesa who succeeded the direction of the city in 2010. To increase scrutiny of procurement processes, Conesa appointed representatives of the opposition to the boards overseeing public procurement (opposition leader of Sant Cugat, personal communication). Further, Conesa finalized the consolidation of the dual organizational structure and together with a new city manager, she continued the performance management agenda and complemented it with the emerging open government paradigm focused on transparency and digital innovation.

\section{Conclusions}

This article has focused on pockets of good government at the subnational level in Spain. We put forward an argument based on the role of the fiduciary relationship between mayors and city managers and specified the conditions under which a trustee system can be implemented successfully. We have illustrated our argument by tracking the path of institutional reform in two medium-sized Spanish cities with a successful record of controlling corruption and above-average performance in transparency and administrative capacity.
Alcobendas and Sant Cugat del Vallès have both followed a remarkably similar reform sequence which differs from the path taken by similar cities in their regions. Both cities implemented a dual organizational model in which elected officials and administrators maintain distinct roles: Political control involves the capacity to set direction and oversee performance results, while implementation is shaped by professional standards and perspectives (Svara, 2001). The implementation of the dual organizational model was carefully phased in over a prolonged period in contexts marked by the sustained support of executive leadership. In contexts where the same actors had successively won elections, but leaders foresaw possible future defeat, the dual organizational model was endorsed by incumbents to signal competence and integrity, while government longevity provided sufficient time for consistent implementation. The politicians' endorsement of administrative reforms fostered the sustained effort of city managers, who drew on the expectation that administrative reforms should be maintained. On the one hand, city managers established a constructive relationship with the executive leadership as they displayed a commitment to accountability and responsiveness to political leaders. On the other hand, city managers were able to overcome administrators' resistance to the implementation of the new organizational model by focusing on strategic planning and performance evaluation.

Much remains to be done to generalize from our case studies that can only articulate issues for further investigation about institutional reforms. In particular, this article contributes to the existing literature dealing with the impact of political competition on the control of corruption by adding a relevant but still overlooked multiarena perspective. We show that political vulnerability also originates from elections in units different from those under investigation (regional elections and local elections in surrounding municipalities). In both cases, the isolation of the parties (Spanish Socialist Party and Convergence and Union) in the region activated strong electoral pressures even if a mayors' grip on local government was stable. The mayors in regions dominated by other parties felt constrained and focused on showcasing their ability as good managers. The existence of such pressures implies that political competition occurring in the units of analysis is not capable of telling the entire story and that multi-arena patterns might be important political determinants of institutional reforms. Hence, the theories dealing with the effect of electoral competition on institutional reforms should take into account the interaction between different electoral arenas and its impact on reforms.

Further, our research contributes to the growing body of literature on within-country variation observed at the subnational level regarding the control of corruption (Erlingsson \& Lundåsen, 2019). Against this background, it is a crucial task to understand the extent to which local authorities may be responsible for producing 
variation within one country. We did this in Spain, a setting with corruption problems, and did indeed find differentiated paths of organizational change across municipalities. A fine-grained analysis of factors affecting institutional innovation at the individual level revealed that two medium-sized cities experienced considerable improvements and benefited from the diffusion of city managers who were able to match political pressures for service delivery to modern managerial solutions. Thus, our findings highlight the relevance of qualitative micro-level analyses of public management reforms for the growing literature on subnational variations in the quality of government in developed countries (Di Mascio \& Natalini, 2013; Ongaro \& Valotti, 2008). The micro-level approach also serves as a bridge between different areas of inquiry, as it resonates with the emerging literature on islands of integrity in developing countries (McDonnell, 2017).

Finally, our findings have important policy implications as they affirm the relevance for local governments of institutional innovations which, by design, create a distance between the political and managerial spheres. Our case-oriented research highlighted that successful control of corruption begins with administrative reform. Given the scarcity of organizational resources at the local level of government, investment should first be directed towards building capacity for strategic planning and performance evaluation rather than being diverted towards the implementation of the international anticorruption toolkit.

\section{Acknowledgments}

This article is the result of a common undertaking. However, the Sections 4 and 5 can be directly attributed to Eliška Drápalová; Sections 1, 2, 3 and 6 to Fabrizio Di Mascio. The authors would like to thank Simona Piattoni and Victor Lapuente for their comments and valuable advice on the early versions of the article. The authors are also grateful to the three anonymous reviewers for their constructive comments to improve the quality of the manuscript.

\section{Conflict of Interests}

The authors declare no conflict of interests.

\section{References}

Ashworth, R. E., McDermott, A. M., \& Currie, G. (2019). Theorizing from qualitative research in public administration: Plurality through a combination of rigor and richness. Journal of Public Administration Research and Theory, 29(2), 318-333.

Bågenholm, A., \& Charron, N. (2014). Do politics in Europe benefit from politicising corruption? West European Politics, 37(5), 903-931.

Bearfield, D., \& Bowman, A. O. M. (2017). Can you find it on the web? An assessment of municipal e- government transparency. Administration \& Society, 47(2), 172-188.

Beeri, I., \& Navot, D. (2013). Local political corruption: Potential structural malfunctions at the central-local, local-local and intra-local levels. Public Management Review, 15(5), 712-739.

Benito, B., Guillamón, M.-D., \& Bastida, F. (2015). Determinants of urban political corruption in local governments. Crime, Law and Social Change, 63, 191-210.

Bennett, A., \& Checkel, J. T. (2014). Process tracing: From metaphor to analytic tool. Cambridge: Cambridge University Press.

Berliner, D. (2014). The political origins of transparency. The Journal of Politics, 76(2), 479-491.

Berliner, D., \& Erlich, A. (2015). Competing for transparency: Political competition and institutional reform in Mexican states. American Political Science Review, 109(1), 110-128.

Broms, R., Dahlström, C., \& Fazekas, M. (2019). Political competition and public procurement outcomes. Comparative Political Studies, 52(9), 1259-1292.

Charron, N., Lapuente, V., \& Annoni, P. (2019). Measuring quality of government in EU regions across space and time. Papers in Regional Science. https://doi.org/ 10.1111/pirs.12437

Coviello, D., \& Gagliarducci, S. (2017). Tenure in office and public procurement. American Economic Journal: Economic Policy, 9(3), 59-105.

Dahlström, C., \& Lapuente, V. (2017). Organizing Leviathan: Politicians, bureaucrats, and the making of good government. Cambridge: Cambridge University Press.

Dahlström, C., Lapuente, V., \& Teorell, J. (2012). Public administration around the world. In S. Holmberg \& B. Rothstein (Eds.), Good government: The relevance of political science (pp. 40-68). Cheltenham: Edward Elgar.

de Sousa, L., Hindess, B., \& Larmour, P. (2009). Governments, NGOs and anti-corruption: The new integrity warriors. London: Routledge.

Di Mascio, F., \& Natalini, A. (2013). Context and mechanisms in administrative reform processes: Performance management within Italian local government. International Public Management Journal, 16(1), 141-166.

Dowding, K. M., \& Kimber, R. (1983). The meaning and use of 'political stability.' European Journal of Political Research, 11(3), 229-243.

Drapalova, E., \& Lapuente, V. (2017). Do city managers improve government performance? Analysis of the effect of city managers in Catalan municipalities? (QoG Institute Working Papers 2017:2). Gothenburg: University of Gothenburg.

Erlingsson, G. Ó., \& Lundåsen, S. W. (2019). When state-level institutions cannot tell the whole story: An inquiry into municipal variations in quality of government. Governance. https://doi.org/10.1111/ gove. 12463 
Esteller-Moré, A., \& Polo Otero, J. (2012). Fiscal transparency: (Why) does your local government respond? Public Management Review, 14(8), 1153-1173.

European Commission. (2014). EU anti-corruption report: Spain (COM(2014) 38 final, Annex 9). Brussels: European Commission.

Fay, D. L., \& Zavattaro, S. M. (2019). Contracting, ethics, and policy adoption: The case of Florida municipalities. Public Integrity, 21(3), 201-319.

Fernandez, A. (2013). El proceso de gerencialización del Ayuntamiento de Barcelona: Aspectos teóricos $y$ pràcticos [The process of managerial reform in the Barcelona City Hall: Theoretical and practical aspects] (Working Paper University of Barcelona No. 314). Barcelona: University of Barcelona.

George, A. L., \& Bennett, A. (2005). Case studies and theory development in the social sciences. Cambridge, MA: The MIT Press.

Grzymała-Busse, A. M. (2007). Rebuilding Leviathan: Party competition and state exploitation in postcommunist democracies. Cambridge: Cambridge University Press.

Hagemann, C. (2019). How politics matters for EU funds' absorption problems: A fuzzy-set analysis. Journal of European Public Policy, 26(2), 188-206.

Heywood, P. M. (2017). Rethinking corruption: Hocuspocus, locus and focus. The Slavonic and East European Review, 95(1), 21-48.

Iglesias Alonso, Á. I. (2006). Gobernanza e innovación en la gestión pública: Alcobendas 1979-2003 [Governance and innovation in public management: Alcobendas 1979-2003]. Madrid: Instituto Nacional de Administración Pública.

Iglesias Alonso, Á. I., \& Villoria, M. (2010). Local political leadership in urban governance and public administration modernisation: The role of the mayor and councillors in a Spanish municipality. Lex Localis, 8(2), 185-201.

InfoParticipa. (2017). Calidad y transparencia de la comunicación pública [Quality and transparency of public communication]. Mapa InfoParticipa. Retrieved from http://www.mapainfoparticipa.com/index/mapa

Jiménez, F. (2009). Building boom and political corruption in Spain. South European Society and Politics, 14(3), 255-272.

Jiménez, F., Quesada-Garcia, M., \& Villoria, M. (2014). Explaining differences in the extent of corruption in three Spanish local governments. International Journal of Public Administration, 37(1), 67-82.

Jiménez, F., Villoria, M., \& Quesada-Garcia, M. (2012). Badly designed institutions, informal rules and perverse incentives: Local government corruption in Spain. Lex Localis, 10(4), 363-381.

Jiménez, F., Villoria, M., \& Romero, J. (2012). (Un)sustainable territories: Causes of the speculative bubble in Spain (1996-2010) and its territorial, environmental and socio-political consequences.
Environment and Planning Government and Policy, 30, 467-486.

Klausen, K. K., \& Magnier, A. (1998). The anonymous leader: Appointed CEOs in Western local government. Odense: University Press of Southern Denmark.

Knott, J. H., \& Miller, G. J. (2008). When ambition checks ambition: Bureaucratic trustees and the separation of powers. The American Review of Public Administration, 38(4), 387-411.

Majone, G. (2001). Two logics of delegation: Agency and fiduciary relationships in EU governance. European Union Politics, 2(1), 103-122.

Marquette, H., \& Peiffer, C. (2018). Grappling with the 'real politics' of systemic corruption: Theoretical debates versus 'real-world' functions. Governance, 31(3), 499-514.

Marquette, H., \& Peiffer, C. (2019). Thinking politically about corruption as problem-solving: A reply to Persson, Rothstein, and Teorell. Governance, 32(4), 811-820.

Martín, V. O. M., \& Darias, L. M. J. (2011). La corrupción urbanística, la crisis actual y el atraso de España: El papel de la renta del suelo [Urban corruption, the current crisis and the backwardness of Spain]. Madrid: EAE Editorial Academia Española.

McDonnell, E. M. (2017). Patchwork Leviathan: How pockets of bureaucratic governance flourish within institutionally diverse developing states. American Sociological Review, 82(3), 476-510.

Mele, V., \& Ongaro, E. (2014). Public sector reform in a context of political instability: Italy 1992-2007. International Public Management Journal, 17(1), 111-142.

Milio, S. (2008). How political stability shapes administrative performance: The Italian case. West European Politics, 31(5), 915-936.

Miller, G. J., \& Whitford, A. B. (2016). Above politics: Bureaucratic discretion and credible commitment. New York, NY: Cambridge University Press.

Ministry of Finance of Spain. (2017). Data bank. Data bank. Retrieved from http://buscadorcdi.gob.es/ Cifra/en/inicio

Mitchell, D. (2018). City managers and the implementation of strategic initiatives. Public Administration, 96(1), 200-217.

Mouritzen, P. E., \& Svara, J. H. (2012). Leadership at the apex: Politicians and administrators in Western local governments. Pittsburgh, PA: University of Pittsburgh Press.

Mungiu-Pippidi, A. (2015). The quest for good governance. Cambridge: Cambridge University Press.

Mungiu-Pippidi, A., \& Dadašov, R. (2016). Measuring control of corruption by a new index of public integrity. European Journal on Criminal Policy and Research, 22(3), 415-438.

Mungiu-Pippidi, A., \& Dadašov, R. (2017). When do anticorruption laws matter? The evidence on public integrity enabling contexts. Crime, Law and Social Change, 68, 387-402. 
Nalbandian, J. (2006). Politics and administration in local government. International Journal of Public Administration, 29(12), 1049-1063.

Nelson, K. L., \& Svara, J. H. (2015). The roles of local government managers in theory and practice: A centennial perspective. Public Administration Review, 75(1), 49-61.

Ongaro, E., \& Valotti, G. (2008). Public management reform in Italy: Explaining the implementation gap. The International Journal of Public Sector Management, 21(2), 174-204.

Ospina, S. M., Esteve, M., \& Lee, S. (2017). Assessing qualitative studies in public administration research. Public Administration Review, 78(4), 593-605.

Palacios, J. L., Fulgueiras, F. J., \& Catalina, C. (2002). La medición de la calidad en la administración local: El caso de los servicios socioculturales del Ayuntamiento de Alcobendas [Measuring quality of local administration: The case of the sociocultural services in Alcobendas]. Dirección y Organización, 28. Retrieved from https://ww.revistadyo.com/index.php/ dyo/article/view/168

Parrado, S., Dahlström, C., \& Lapuente, V. (2018). Mayors and corruption in Spain: Same rules, different outcomes. South European Society and Politics, 23(3), 303-322.

Persson, A., Rothstein, B., \& Teorell, J. (2013). Why anticorruption reforms fail: Systemic corruption as a collective action problem. Governance, 26(3), 449-471.

Persson, A., Rothstein, B., \& Teorell, J. (2019). Getting the basic nature of systemic corruption right: A reply to Marquette and Peiffer. Governance, 32(4), 799-810.

Piattoni, S., \& Smyrl, M. (2002). Building effective institutions: Italian regions and EU structural funds. In J. Bukowski, S. Piattoni, \& M. Smyrl (Eds.), Between Europeanization and local societies: The space for territorial governance in Europe (pp. 133-156). Boulder, CO: Rowman \& Littlefield.

Pollitt, C. (2008). Time, policy, management: Governing with the past. Oxford: Oxford University Press.

Pollitt, C., \& Bouckaert, G. (2014). Public management reform: A comparative analysis. Oxford: Oxford University Press.

Ramió, C., \& Salvador, M. (2012). Provisión de servicios públicos en el contexto de la administración local de España: El papel de los factores políticos institucionales y la externalización de los gobiernos locales [Provision of public services in the context of the local administration: The role of political factors and the outsourcing of local governments]. Gestión Y Política Pública, 21(2), 375-405.

Rauch, J. E., \& Evans, P. B. (2000). Bureaucratic structure and bureaucratic performance in less developed countries. Journal of Public Economics, 75, 49-71.

Recoder, L., \& Joly, J. (2010). La política que ve: Competitividad pública per afrontar els reptes del segle XXI [Real impact of politics: Public competitiveness to face the challenges of the 21st century]. Barcelona: Proa and La Mirada.
Rubin, E. V., \& Baker, K. P. (2019). Paying attention to the trees in the forest, or a call to examine agencyspecific stories. Review of Public Personnel Administration, 39(4), 532-543.

Salvador, M., \& Pano, E. (2018). Mayors facing local Government reforms: From municipal organization leadership to public management transformation processes. Revista Española de Ciencia Política, 46, 103-127.

Sampson, S. (2010). The anticorruption industry: From movement to institution. Global Crime, 11(2), 261-278.

Sancino, A., \& Turrini, A. (2009). The managerial work of Italian city managers: An empirical analysis. Local Government Studies, 35(4), 475-491.

Schnell, S. (2018). Cheap talk or incredible commitment? (Mis)calculating transparency and anti-corruption. Governance, 31(3), 415-430.

Snyder, R. (2001). Scaling down: The subnational comparative method. Studies in Comparative International Development, 36(1), 93-110.

Svara, J. H. (2001). The myth of dichotomy: Complementarity of politics and administration in the past and future of public administration. Public Administration Review, 61(2), 176-183.

Sweeting, D. (2012). Analysing local political management in Spain. Local Government Studies, 38(2), 231-247.

Tavares, A., \& da Cruz, N. (2017). Explaining the transparency of local government websites through a political market framework. Government Information Quarterly. https://doi.org/10.1016/j.giq.2017. 08.005

Tejedo-Romero, F., \& Araujo, J. F. (2020). E-governmentenabled transparency: The effect of electoral aspects and citizen's access to Internet on information disclosure. Journal of Information Technology and Politics. https://doi.org/10.1080/19331681.2020.1713958

Turull i Negre, J., \& Vivas Urieta, C. (2003). El cuadro de mando integral en la administración pública: El caso del Ayuntamiento de Sant Cugat del Vallès [The balanced scorecard in public administration: The case of the Sant Cugat del Vallès]. Paper presented at the VIII International Congress of CLAD on State Reform and Public Administration, Panama.

van Dorp, E. J. (2018). Trapped in hierarchy: The craft of Dutch city managers. Public Management Review, 20(8), 1228-1245.

Villoria, M. (2020). Corruption and transparency. In D. Muro \& I. Lago (Eds.), The Oxford handbook of Spanish politics (pp. 629-645). Oxford: Oxford University Press.

Wollmann, H. (2012). Local government reforms in (seven) European countries: Between convergent and divergent, conflicting and complementary developments. Local Government Studies, 38(1), 41-70.

Yin, R. K. (2014). Case study research: Design and methods. Thousand Oaks, CA: Sage. 


\section{About the Authors}

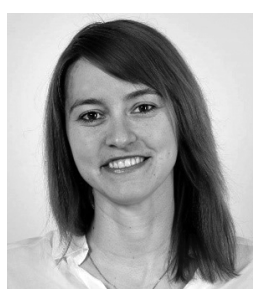

Eliška Drápalová is a Postdoctoral Fellow at the University of Gothenburg at the Quality of Governance Institute. Her research focuses on administrative capacity, subnational quality of government, corruption, the effect of party competition on public services, and bureaucratic quality.

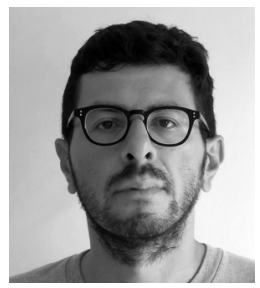

Fabrizio Di Mascio is Associate Professor of Political Science at the University of Turin. His comparative research focuses on public management reform, open government, and regulatory governance. 